\title{
Development and Characterization of Simple Sequence Repeats (SSR) as Markers to Identify Strawberry Cultivars (Fragaria $\times$ ananassa Duch.)
}

\author{
Katsumi Shimomura* and Keita Hirashima \\ Fukuoka Agricultural Research Center, Chikusino 818-8549, Japan
}

\begin{abstract}
The octoploid cultivated strawberry, Fragaria $\times$ ananassa Duch., is one of the most important commercial fruit species in Japan. Recently, cultivars developed in Japan are being used in other countries and the products are exported to Japan without the permission of breeders. Therefore, we need a way to protect breeders' rights. So, we newly developed four simple sequence repeats (SSR) as markers to establish a more reliable method for the identification of strawberry cultivars $(F . \times$ ananassa $)$. Especially, the frequency of two marker polymorphisms was high, and they facilitated the detection of 10 major Japanese commercial strawberry cultivars. The results indicated that the SSR markers were specific enough to identify octoploid strawberry cultivars for the protection of breeders' rights.
\end{abstract}

Key Words: cultivar, DNA, identification, SSR, strawberry.

\section{Introduction}

The octoploid cultivated strawberry, Fragaria $\times$ ananassa Duch., is one of the most important commercial fruit species in Japan. New strawberry cultivars are being developed at many institutes for farmers and customers. Of recent concern is the problem of cultivars being developed in Japan and used in other countries, and even exported to Japan without the permission of breeders. So, we need a method for the protection of breeders' rights.

There are several DNA fingerprinting techniques, RAPD, RFLP, AFLP, and SSR etc., for the genetic analysis or identification of varieties (Akkaya et al., 1992; Gianfranceschi et al., 1998; Powell et al., 1996; Sharma et al., 1996; Yamamoto et al., 2001). A great deal of genetic research on strawberry cultivars has been done concerning fruit bearing, fruit quality, and disease resistance, etc., for breeding new cultivars (Inoue et al., 1997; Matsuda et al., 1988; Monma et al., 1990; Mori, 2000; Mori and Kitamura, 2001; Takahashi et al., 1991). Recently, some molecular scientific research has been reported in the strawberry (Ashley et al., 2003; Folta et al., 2005; James et al., 2003; Lerceteau-Köhler et al., 2003). However, the amount of research is still insufficient compared with other major crops, e.g., rice and wheat. Folta et al. (2005) reported that the octoploid genome presented a formidable barrier to the efficient study of genome structure and molecular mechanisms

Received; November 4, 2005. Accepted; April 12, 2006.

This work was supported by a research project for utilizing advanced technologies in agriculture, forestry and fisheries.

* Corresponding author (E-mail: kshimo@farc.pref.fukuoka.jp). that underlie agriculturally relevant traits. It was reported that the development of microsatellite markers for polyploid plant species lagged behind that of diploid species and despite the economic importance of the cultivated strawberry ( $F . \times$ ananassa) (Ashley et al., 2003).

Most Japanese commercial strawberry cultivars are octoploid and their molecular information is too restricted compared with the major crops for developing a detection method for those cultivars directly. AFLP is known to be one of the most available methods for genetic analysis without sequence information. So, we examined whether AFLP was suitable for the detection of strawberry cultivars and reported that it was indeed useful for the identification of major Japanese commercial strawberry cultivars (Shimomura et al., 2005). However, detection methods are required with the highest reliability possible. Generally, AFLP is available to accumulate many polymorphisms in one experiment, and its reproducibility is higher than RAPD. Whereas, SSR markers have several advantages over other molecular markers, which provide a more reliable method for DNA fingerprinting because of their codominant inheritance, large number of alleles per locus, and abundance in genomes (Yamamoto et al., 2001). For the strawberry, James et al. (2003) reported that SSR markers were sufficient to distinguish between accessions in the diploid wild strawberry, $F$. vesca $\mathrm{L}$.

In this study, we newly developed SSR markers from the octoploid cultivated strawberry cultivar, 'Toyonoka $(F . \times$ ananassa $)$ ', to establish a more reliable DNA fingerprinting technique, and examined whether SSR was suitable for the identification of octoploid strawberry cultivars. 


\section{Materials and Methods}

\section{Plant materials}

DNA of 'Toyonoka', which is one of the most famous commercial cultivars in Japan, was used for the development of SSR markers. Ten major Japanese commercial strawberry cultivars $(F \times \times$ ananassa), 'Toyonoka', 'Sachinoka', 'Fukuoka S6', 'Nyohou', 'Tochiotome', 'Asukaruby', 'Akihime', 'Redpearl', 'Sagahonoka', and 'Aiberry', were tested for the identification of octoploid strawberry cultivars. These strawberry cultivars were all the same as in our AFLP study (Shimomura et al., 2005).

\section{Constructing a genomic library and screening clones} enriched with repeat sequences

DNA was extracted from the octoploid strawberry 'Toyonoka' as follows. Fifty mg of fresh leaf tissue placed in a $2 \mathrm{~mL}$ tube was frozen in liquid nitrogen and broken with the multi beads shocker system (Retsch, Germany) to obtain tissue powder. Then, the powder was suspended in $1 \mathrm{~mL}$ extraction buffer $(50 \mathrm{mM}$ Tris$\mathrm{HCl}, \quad 5 \mathrm{mM}$ EDTA, $350 \mathrm{mM}$ sorbitol, and $10 \%$ PEG6000), 0.1\% mercaptoethanol was added, and it was centrifuged at $5000 \times \mathrm{g}$ at $4^{\circ} \mathrm{C}$. DNA was extracted from the pellet with Nucleon PHYTOPURE (Amasham LIFE SCIENCE, UK) and dissolved in TE buffer (10 mM Tris$\mathrm{HCl}, 1$ mM EDTA, pH 7.5). Genomic DNA was digested with EcoRI or Hind III to provide $300 \mathrm{bp}$ to $500 \mathrm{bp}$ fragments after $1.5 \%$ agarose gel electrophoresis. DNAs were eluted from gels with the QIAquick Gel Extraction Kit (QIAGEN, USA), ligated into plasmids, pBluescript II (STRATAGENE, USA), and transformed into Escherichia coli competent cells, XL1-Blue (TaKaRa, Japan). We obtained clones enriched with repeat sequences after screening by dot-blot hybridization using biotin-labeled $(\mathrm{AG})_{10}$ or $(\mathrm{AT})_{10}$ probes and the DNA $\mathrm{HyBr} \&$ Detection Kit (PALL, USA). Positive clones were grown overnight to obtain plasmid DNAs for sequencing.

Design of primers and amplification for SSRs PCR products were amplified from plasmid DNAs obtained from clones selected after screening the genomic library. Then, PCR was performed with the Big Dye Terminator v3.0 Ready Reaction Cycle Sequencing Kit (PE Applied Biosystems, USA) using the PCR products. Sequencing was carried out with an ABI 310 automated sequencer (PE Applied Biosystems). We designed primers to amplify each simple sequence repeat using the program GENETYX ver. 6.0 (GENETYX, Japan) after sequencing.

Primers designed were tested for the identification of ten strawberry cultivars. PCR amplification was carried out in $50 \mu \mathrm{L}$ of reaction mixture containing $200 \mu \mathrm{M}$ of each dNTP, $0.5 \mu \mathrm{M}$ of each primer, $50 \mathrm{mM} \mathrm{KCl}, 2 \mathrm{mM}$ $\mathrm{MgCl}_{2}$, and $1.25 \mathrm{U}$ ExTaq polymerase (TaKaRa). Amplification was performed with PROGRAM TEMP CONTROL SYSTEM PC-808 (ASTEC, Japan). PCR reactions consisted of a 2 -min pre-heat at $95^{\circ} \mathrm{C}$ followed by 35 cycles of denaturing at $94^{\circ} \mathrm{C}$ for $60 \mathrm{~s}$, annealing at $55^{\circ} \mathrm{C}$ for $60 \mathrm{~s}$, extension at $72^{\circ} \mathrm{C}$ for $2 \mathrm{~min}$, and a final extension at $72^{\circ} \mathrm{C}$ for $10 \mathrm{~min}$.

\section{Identification of strawberry cultivars}

DNAs were extracted from 10 strawberry cultivars tested. PCR products were amplified from the DNAs using the primers. Extraction and amplification were performed as described previously. DNA products were separated on $5 \%$ denaturing polyacrylamide gels containing $7 \mathrm{M}$ Urea, as described by William et al. (2005).

\section{Results and Discussion}

In this study, we obtained about one thousand clones, and four SSR clones were selected from them for repeat sequences after screening the genomic library. They were obtained from dot-blot hybridization using biotin-labeled $(\mathrm{AG})_{10}$ probes. Three were $(\mathrm{GA} / \mathrm{CT}) \mathrm{n}$ repeats and one was a (CA/GT)n repeat. Four primers were designed for the amplification of sequence repeats (Table 1). All of them were able to amplify the DNA of 'Toyonoka' at the expected size. There were one to five bands on polyacrylamide gels in strawberry cultivars tested. Two or three bands were the same size in tested cultivars, although the polymorphism level was not low.

Table 1. Primers designed for SSR.

\begin{tabular}{cclc}
\hline \hline Name & Motif & \multicolumn{1}{c}{ Sequence (5'-3') } & Expected length $^{\mathrm{z}}(\mathrm{bp})$ \\
\hline Fa1A-6 & $(\mathrm{GA})_{26}$ & F: CCACCCTCCAATATAACCC & 190 \\
& & R: AGGAGAACCAAGATTAAGCC & 203 \\
Fa2A-6 & $(\mathrm{CT})_{10}$ & $\begin{array}{l}\text { F: GGAGGTTTGAAACCAAAGCC } \\
\text { R: CACTGTCCAGTTCCCTTTCC }\end{array}$ & 226 \\
& & F: TCTGCTTCTCTTGAACTGG & \\
Fa3C-2 & $(\mathrm{AC})_{3}$ & R: GTATCTGGAGCCAAGAGG & 343 \\
& $(\mathrm{CT})_{14}$ & F: AGGACAACTTCGAGAAGG & \\
& & R: CGAATTCGCTCTTCACAG & \\
\hline
\end{tabular}

${ }^{\mathrm{z}}$ The expected length was determined based on the sequencing results for isolated clones from 'Toyonoka'. 
Table 2. Amplified fragment patterns of primers developed for SSR analysis from 10 strawberry cultivars.

\begin{tabular}{lcl}
\hline \hline \multirow{2}{*}{ Cultivars } & \multicolumn{2}{c}{ Primers } \\
\cline { 2 - 3 } & Fa1A-6 & Fa2A-6 \\
\hline Toyonoka & acdef & acde \\
Sachinoka & acdf & acde \\
FukuokaS6 & acde & acdef \\
Nyohou & bcdf & abdef \\
Tochiotome & bcd & acdef \\
Asukaruby & abcdf & acdef \\
Redpearl & acdf & bcdef \\
Sagahonoka & cdf & cdef \\
Akihime & cdf & adef \\
Aiberry & cdef & abdef \\
\hline
\end{tabular}

${ }^{\mathrm{z}}$ indicates bands on Fig. 1 and Fig. 2, respectively.

Especially, two primers, Fa1A-6 and Fa2A-6, revealed high levels of polymorphism (Table 2). They could distinguish between all ten of the strawberry cultivars tested, and polymorphisms were available at a high frequency for identification (Figs. 1 and 2). It was reported that the level of SSR polymorphisms was surprisingly low in the diploid wild strawberry, $F$. vesca (James et al., 2003). But, the levels of our newly developed SSR markers polymorphisms, Fa1A-6 and Fa2A-6, were not low, and those markers were specific and available for the identification of octoploid strawberry cultivars in this study. We think that the levels of these SSR marker polymorphisms were not low because the octoploid strawberry had four times the loci of the diploid variety. Although the levels of the other two SSR markers, Fa3C-2 and Fa4A-1, were not high.

Ashley et al. (2003) developed several SSR markers for the octoploid wild strawberry F. virginiana Duch., and reported that those markers were able to amplify products in the cultivated strawberry, $F$. $\times$ ananassa. The cultivated strawberry $F$. $\times$ ananassa originated from chance hybridizations that occurred in some Europian botanical gardens between two octoploid species, $F$. virginiana and $F$. chiloensis Duch. (Lerceteau-Köhler et al., 2003). This indicates that SSR markers originating from octoploid strawberries should enable the establishment of a more reliable and useful DNA fingerprinting technique for the identification of octoploid strawberry cultivars. Furthermore, SSRs have a high degree of polymorphism and are suitable for automation (Weber and May, 1989). We have to try making a catalogue of many other strawberry varieties using SSR markers.

Recently, Kunihisa et al. (2003) reported CAPS was able to identify 14 commercial cultivars and is available for protecting breeders' rights. Detection reliability may be elevated via using several different techniques in the strawberry.

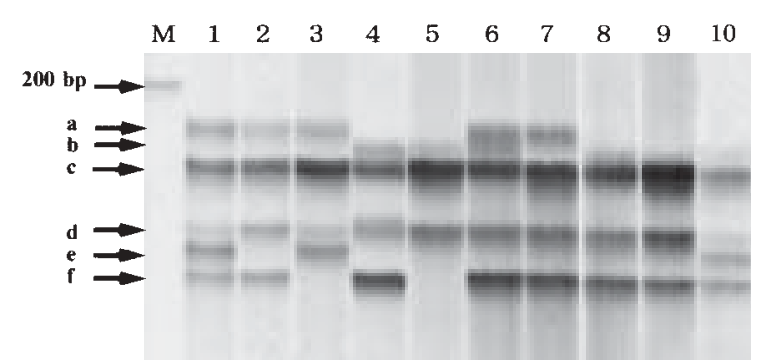

Fig. 1. SSR profile shown by FalA-6 primers after 5\% PAGE denatured by $7 \mathrm{M}$ urea. Lane M; 100 bp DNA ladder marker: lanes 1 to 10; 'Toyonoka', 'Sachinoka', 'FukuokaS6', 'Nyohou', 'Tochiotome', 'Asukaruby', 'Redpearl', 'Sagahonoka', 'Akihime', and 'Aiberry', respectively. The arrows, a to f, indicate bands from the alleles of cultivars.

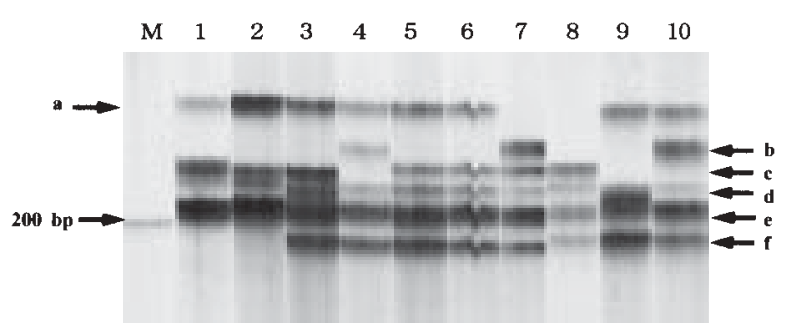

Fig. 2. SSR profile shown by Fa2A-6 primers after 5\% PAGE denatured by $7 \mathrm{M}$ urea. Lane $\mathrm{M}$, lanes 1 to 10 , and the arrows indicate the same as in Fig. 1.

\section{Acknowledgements}

We wish to thank Dr. Masayoshi Shigyo, Ms. Noriko Matsubara (Yamaguchi University), and Mr. Shinichi Masuzaki (Tottori University) for their support of the experiment of polyacrylamide gel electrophoresis in this study.

\section{Literature Cited}

Akkaya, M. S., A. A. Bhagwat and P. B. Cregan. 1992. Length polymorphisms of simple sequence repeat DNA in soybean. Genetics 32: 1131-1139.

Ashley, M. V., J. A. Wilk, S. M. N. Styan, K. J. Craft, K. L. Jones, K. A. Feldheim, K. S. Lewers and T. L. Ashman. 2003. High variability and disomic segregation of microsatellites in octoploid Fragaria verginiana Mill. (Rosaceae). Ther. Appl. Gen. 107: 1201-1207.

Folta, K. M., M. Staton, P. J. Stewart, S. Jung, D. H. Bies, C. Jesdurai and D. Main. 2005. Expressed sequence tags (EST's) and simple sequence repeat (SSR) markers from octoploid strawberry (Fragaria $\times$ ananassa). BMC Plant Biology. 5: 12.

Gianfranceschi, L., N. Seglias, R. Tarchini, M. Komjanc and C. Gessler. 1998. Simple sequence repeats for the genetic analysis of apple. Theor. Appl. Genet. 96: 1069-1076.

Inoue, J., K. Ueno, N. Kita, T. Takeda and Y. Nakazawa. 1997. Breeding of strawberry for powdery mildew resistance. 1. Differential resistance of strawberry varieties to powdery mildew and genetic analysis of the resistance. J. Japan. Soc. Hort. Sci. 66 (Suppl. 2): 460 (In Japanese). 
James, C. M., F. Wilson, A. M. Hadonou and K. R. Tobutt. 2003. Isolation and characterization of polymorphic microsatellites in diploid strawberry (Fragaria vesca L.) for mapping, diversity studies and clone identification. Mol. Ecology 3: 171-173.

Kunihisa, M., N. Fukino and S. Matsumoto. 2003. Development of cleavage amplified polymorphic sequence (CAPS) markers for identification of strawberry cultivars. Euphytica 134: 209-215.

Lerceteau-Köhler, E., G. Guerin, F. Laigret and B. DenoyesRoyhan. 2003. Characterization of mixed disomic and polysomic inheritance in the octoploid strawberry (Fragaria $\times$ ananassa) using AFLP mapping. Theor. Appl. Genet. 107: 619-628.

Martin, W. J., J. McCallum, M. Shigyo, J. Jakse, J. C. Kuhl, N. Yamane, M. Pither-Joyce, A. F. Gokce, K. C. Sink, C. D. Town and M. J. Havey. 2005. Genetic mapping of expressed sequences in onion and in silico comparisons with rice show scant colinearity. Mol. Gen. Genet. 274: 197-204.

Matsuda, T., H. Hara and M. Izaki. 1988. Inheritance of some characteristics in the strawberry (Fragaria $\times$ ananassa Duch.). Sci. Rep. Fac. Agr. Ibaraki Univ. 36: 1-18 (In Japanese with English summary).

Monma, S., S. Okitsu and K. Takada. 1990. Inheritance of everbearing habit in strawberry. Bull. Natl. Res. Inst. Veg., Ornam. Plants Tea Japan, Ser. C. 1: 21-29 (In Japanese with English summary).

Mori, T. 2000. Heritability and selection effectiveness for fruit firmness in strawberry. J. Japan. Soc. Hort. Sci. 69: 90-
96 (In Japanese with English summary).

Mori, T. and H. Kitamura. 2001. Inheritance of the earliness habit in June-bearing strawberry. J. Japan. Soc. Hort. Sci. 70 (Suppl. 2): 171 (In Japanese).

Powell, W., M. Morgante, C. Andre, M. Hanafey, J. Vogal, S. Tingey and A. Rafalski. 1996. The comparison of RFLP, RAPD, AFLP and SSR (microsatellite) markers for germplasm analysis. Mol. Breed. 2: 225-238.

Sharma, S. K., M. R. Knox and T. H. N. Ellis. 1996. AFLP analysis of the diversity and phylogeny of lens and its comparison with RAPD analysis. Theor. Appl. Gen. 93: 751-758.

Shimomura, K., H. Mitsui, K. Fujita and K. Satoh. 2005. Identification of strawberry cultivar 'Fukuoka S6 (Fragaria $\times$ ananassa Duch.)' by amplified fragment length polymorphism. Bull. Fukuoka Agric. Res. Cent. 24: 43-47 (In Japanese with English summary).

Takahashi, H., T. Takai and T. Matsumoto. 1991. Inheritance of susceptibility of strawberry cultivars to Alternaria alternata strawberry pathotype. J. Japan. Soc. Hort. Sci. 60: 113-118 (In Japanese with English summary).

Weber, J. K. and P. E. May. 1989. Abundant class of human DNA polymorphisms which can be typed using the polymerase chain reaction. Am. J. Hum. Genet. 44: 388 397.

Yamamoto, T., T. Kimura, M. Shouda, Y. Ban, T. Hayashi and N. Matsuta. 2002. Development of microsatellite markers in the Japanese pear (Pyrus pyriforia Nakai) Mol. Ecology Notes 2: 14-16.

イチゴ (Fragaria×ananassa Duch.) の品種識別のための SSR マーカーの開発とその性状

\author{
下村克己・平島敬太 \\ 福岡県農業総合試験場８18-8549 筑紫野市吉木
}

近年, 国内で育成されたイチゴやインゲン等の品種の
海外での違法使用, 生産物の逆輸入が増加し問題となっ
ている. そこで, そらした違法使用抑制を目的にイチゴ
のSSR マーカーを開発し, その品種識別に拈ける有効性
を検討した. 開発した 4 つの SSR マーカーのらち 2 つ
は多型性が特に高く，これらにより供試した主要栽培 10 品種の識別が可能であった。 このことから，SSR は八倍 体であるイチゴ栽培品種の識別にも有効と考えられ，今 回開発した SSR マーカーは, 育成者権益の確保に役立つ ことが期待できると考えられた。 